\title{
Comforting Discomfort: A Review of Warrior Women: Remaking Postsecondary Places Through Relational Narrative Inquiry
}

\author{
Lace Marie Brogden \\ University of Regina
}

As an academic from the Canadian prairies with a background in narrative, I found Warrior Women: Remaking Postsecondary Places Through Relational Narrative Inquiry by Mary Isabelle Young, Lucy Joe, Jennifer Lamoureux, Laura (Lulu) Marshall, Sister Dorothy Moore, Jerry-Lynn Orr, Brenda Mary Parisian, Khea Paul, Florence Paynter, and Janice Huber (2012) to be, from a theoretical perspective, a comfortable, even familiar read; the "usual suspects" of narrative inquiry (Jean Clandinin, Michael Connelly, Trinh Minh-Ha, and others) and narrative more generally (Mary Catherine Bateson, Thomas King, Audrey Lorde, and so on) are present throughout the book. In addition, the book draws on well-known Indigenous scholars (Marie Battiste, Greg Cajete, Linda Tuhiwai Smith, and many more) to frame and promote the importance of decolonizing education and creating more inclusive and generous spaces for Aboriginal learners in postsecondary settings.

If, on the one hand, this brief introduction does not lead to a sense of familiarity and comfort from a narrative perspective, then this book may prove a worthwhile read as an accessible introduction to many relevant authors in the field of narrative inquiry generally, and narrative inquiry in educational research more specifically. Furthermore, readers looking for an introduction to imperatives for Indigenizing research and for calls to decolonize the academy may also find this volume useful and informative.

If, on the other hand, readers of this review find resonance and comfort with the canonical references of my opening paragraph, or have been produced to believe (regrettably) that if “it” is about Aboriginal learners then “it” isn’t really about everyone, then beware complacency!

Indeed, as Elder-author Sister Dorothy Moore, C.M., shares in a composed word image:

Throughout my life I have learned

That the racism

The colonization

Is not going to go away tomorrow or next year

But, we can't stop fighting

We have to keep on fighting. (Young et al., 2012, p. 28)

This excerpt is from one of many word images composed from the authors' individual stories, which are all, in one or more ways, stories of the ongoing effects of colonialism on Aboriginal peoples of Canada. These word images are used throughout the main body of the book to provide a narrative distillation of the "stories to live by" (Young et al., 
2012, after Connelly \& Clandinin, 1999), shared during the seven years of this relational narrative inquiry research project. Although there are occasional disruptions to the fluidity of voice because of the various roles (subject, narrator, autobiographer, researcher), the authors occupy, throughout the work, a collective approach to authorship. All of the women involved share authorial voice, both individually because of their participation in the project, and collectively through the narrative circles held during the course of the research.

\section{Synthesis}

As the genre of review dictates, the book is organized as follows:

- The work begins with a Foreward by Marie Battiste. As one has come to expect from this insightful and prolific scholar, this brief foreword offers succinct yet profound observations on the contemporary dynamics of the continually contested landscapes of (post-secondary) education in Canada and of the learners who bring their stories to these educational spaces. I recommend reading this brief section as both foreword and after-afterword because, read in this way, it completes the narrative circle of this particular work in a hopeful and also demanding way.

- Chapter 1, "Not Tomorrow... Today," introduces the voices of the work, describes the context of the research, and situates the book as calling for action to decolonize post-secondary education spaces in a relational way.

- Chapters 2 through 7 offer, in this reviewer's opinion, the most engaging-and heartbreaking and depressing and uplifting - contributions of the work. Each is organized around a common theme, and uses the aforementioned narrative device of first-person word images, combined with short sections of academic, narrative analysis in third-person voice to connect thematic threads between the authors. In each chapter, connections are made to "intergenerational narrative reverberations" (Young et al., 2012, p. 49) of colonization such as residential schools, poverty, and systemic, institutionalized racism. Although I strongly recommend reading the book sequentially, graduate students and researchers looking to read in particular aspects of narrative inquiry will likely find the discussion of relational narrative inquiry in Chapter 3 useful from a methodological perspective, just as students and instructors in teacher education will find Chapters 6 and 7 useful for thinking about ways to attend to relationality and work to improve, voire transform, learning in preservice teacher education contexts.

- Chapter 8 offers a conclusion to the project in the form of polyvocal reflections and a narrative sharing of the authors' hopes for changes to post-secondary education, and particularly post-secondary teacher education.

- Continuing past the reference list, the reader finds an afterword by Jean Clandinin, mentor to both Young and Huber, and participant as a listener-observer throughout the project. (A critique can be levied here toward the publisher rather than the authors for tucking this useful commentary away at the back of the book, as those not undertaking a book review might well stop turning pages beyond a cursory perusal of the reference list.) 


\section{Commentary on the Discomforting Contributions of Warrior Women}

Over a period of two months, I picked up this book many times, barely getting past the first few pages of Chapter 1. I read a page, or two, and then hesitated. These hesitations might themselves be reflective of some of the books tensions: Relational narrative inquiry is not convenient, engaging in discussions and negotiating understandings about the ongoing violences perpetuated by colonialism are not pleasant, and thinking deeply about the imperatives to transform one's own practice can be destabilizing. Although a comfortable and accessible read from a writing perspective, the content of this book is discomforting and deals with a wide range of human experiences related to systemic oppression.

One northern, November afternoon, however (one of those days when the modern convenience of central heating still needs a boost from the insulation of draperies drawn but not closed so as to fight off wind-chill and blowing snow against the window whilst still ceding admission to fleeting, precious hours of natural light), I sat down with a hot cup of coffee, embraced my growing measure of discomfort, and read the whole book, pretty much straight through. The dedication of the authors themselves demonstrate to be inconvenienced, to take on discussions of silences and pain associated with the colonial reverberations of being Aboriginal in Canada, and their invitation to teacher educators to be courageous in decolonizing the academy are the reasons that make engaging with this book worthwhile.

Corridors long empty silent

I had always enjoyed school

But I was beginning to dislike it a lot

The significant connections between place and identity in being and becoming

Stay[ing] wakeful

Possibilities of Aboriginal and non-Aboriginal educators and post-secondary students working in relation With one another, together learning how to walk in good ways

Experience learning

Which no longer entails needing to give up or erase

Aboriginal rights and the plight of Aboriginal people in Canada is such a huge messy hot topic

We each face complexities as we are composing our lives

I was shocked because he was a sociologist yet, he seemed to be so racist 
Visiting a child who has been affected by the ongoing impact of colonization

The loss of the Mi'kmaq language is as important as the loss of the French language

You should be ashamed of yourself

I missed the security I felt when I lived in my home community

I wonder if we will ever live in a time when all of Canada's peoples will celebrate National Aboriginal Day on June $21^{\text {st }}$

She left because she grew tired of fighting the racism of her colleagues

And the university administration

The last straw happened one day when this upper middle class male student

Told her she was nothing [...] because he didn't like the mark she gave him on a paper

No consequences for living out this racist story

When will this sense of helplessness end for us?

The potential of counterstories to resist and undermine a dominant narrative Gradually shifting our stories to live by

The potential to shape new possible intergenerational narrative reverberations

It is my hope that whoever is out there who picks up this book, and who might have preconceived ideas, back attitudes, feelings about First Nations people, and those come from way

If that person picks up this book

Is re-educated

[and says]

Now I know, now I know, and now I want to change it

Take time to listen to the stories 
We can never give up hope

And especially for one another

(After the authors, this word image is composed of interpretations of Warrior Women: Remaking Postsecondary Places through Relational Narrative Inquiry - all words except those in square brackets[ ] are credited to Young et al. (2012), although page numbers have been excluded for the purposes of narrative coherence.)

\section{Collective Hope}

The places and themes presented in this relational narrative inquiry are to me, a White, language teacher-educator working and living in Saskatchewan, both hauntingly familiar and painfully abstract. The authors express their hope that professors of education will read their book. And I share their hope. It is also a book that should be shared with preservice teacher education students, and in-service teachers doing graduate work. Indulging momentarily in examining its offerings to my field of language teacher education, it has much to offer those grappling with issues of language and power (French/English, Colonial/Indigenous, and so on). Teachers of mathematics will find similar resonance, as will teachers of English, and, for that matter, anyone who has endeavoured to think mindfully, or be “wakeful” (Young et al., 2012) to use the authors' preferred term, when planning for classroom management in a school setting, or when working with adults in a university setting.

Although the authors claim to want to transform post-secondary education, their offering is one of advancing the conversation rather than providing practical or pragmatic suggestions. Indeed, this is perhaps enough as the book stands as an example of building relational communities of learning based on patience, trust, and engagement. As Thomas King (2003) echoes still and again: Do with the stories of these ten women what you will, "but don't say in the years to come that you would have lived your life differently if only you had heard this story. You've heard it now” (p. 151). Much like the challenging and as yet un-resolved issues Canada faces as a nation with regards to reconciliation, shared governance, and living respectfully with Treaty, relational undertakings are timeconsuming and do not lend themselves to easy solutions - rather, it is up to each of us to engage in the challenges of transforming the spaces in which we learn, teach and live. 


\section{References}

Connelly, F. M., \& Clandidin, D. J. (1999). Shaping a professional identity: Stories of educational practice. New York, NY: Teachers College Press.

King, T. (2003). The truth about stories: A Native narrative. Toronto, ON: House of Anansi.

Young, M. I., Joe, L., Lamoureux, J.,Marshall, L., Moore, D., Orr, J-L., Parisian, B. M., Paul, K., Paynter, F., \& Huber, J. (2012). Warrior Women: Remaking postsecondary places through relational narrative inquiry. Bingley, UK: Emerald Group Publishing. 